\title{
TRANSLATION IN FOREIGN LANGUAGE TEACHING AT UNIVERSITY LEVEL
}

Deja Piletić, University of Montenegro, dejap@ucg.ac.me

10.31902/fII.27.2019.15

UDK 811'25

\begin{abstract}
There are different attitudes towards the use of translation in foreign language teaching, which are often split between two extremes. This paper will aim to present the positive views on the role of translation within language degrees in general, and in particular in those situations when there is a lack of nation-wide professional schools and university courses specialized in translator training. As a contribution to a positive perspective of pedagogical translation at university level, the paper will reveal the results of a survey conducted among the undergraduate students from the language departments at the Faculty of Philology of the University of Montenegro. The survey had a goal to find out about the students' views on the role of translation exercises in acquiring both language competence and translation competence.
\end{abstract}

Keywords: pedagogical translation, translation competence, translation didactics, language teaching, language competence, university level

\section{Introduction}

A lot before it became the subject of specific scientific studies, translation had been the main method of studying and teaching foreign languages. Although today's scientific research focuses its attention more on the very nature of translation as activity, translation is still connected to the teaching context, whether we talk about translation in glottodidactics or about translation didactics.

Even though it is much easier to separate them and draw a boundary between them in theory than in practice, we can generally differentiate between three teaching activities which all include translation but in a different way and with a different aim. These are: language teaching, the education and training of translators, and translation teaching at the university studies of foreign languages.

\subsection{Translation and Language Teaching}

Whenever translation and language teaching are found in the same context, the notion of the grammar-translation method becomes inevitable. Contemporary authors mostly agree about the obsolescence of this way of language learning, especially if its 
traditional model is taken into consideration. Although in its long history of existence and application, this method has undergone changeable destiny, it is, in a more or less modified version, still present today at different language learning levels, but with an important difference: translation is no longer the only language exercise, whereas the acquisition of grammar is not the sole aim of language learning.

In reference books, translation used in foreign language teaching is called pedagogical, or glottodidactic translation. In other words, it serves as a means in foreign language learning and teaching, and includes:

- translation functioning as a language exercise;

- translation functioning as knowledge assessment, in which case translation into a foreign language is mainly used for testing the production in the foreign language, while the translation into the mother tongue is used for testing the comprehension of the written text;

- explicative translation, that is the explanation of new language content.

There are many studies on the use and purposefulness of pedagogical translation (e.g. Peverati 2014, Druce 2012, 2015, González Davies, M 2007, Malmkjaer 1998, Sewell and Higgins 1996, Lavault 1985). This will be somewhat discussed later in the paper.

\subsection{Translation and Translation Didactics - translator education and training}

An increased interest in translation, especially over the last tree decades, has also lead to a higher degree of interest in its didactics. More specifically, with an increase in the awareness of the importance of translation, there has been rapid development of the study of translation, while the sole act of translation has been elevated to an academic level: one becomes a professional translator after obtaining a university degree, mainly after attending specialist or postgraduate studies, whereas translation is seen not only as a skill which requires bilingual competence and "a natural gift", but also as a skill which is a combination of theoretical knowledge and practice. Therefore, in the context of translation and teaching, there is another kind of translation which attracts an increasingly great interest among authors and experts in the translation study and applied linguistics. This is the translation applied within translation schools, institutes, and faculties, which, along with an increase in the interest in this activity, 
are becoming more and more widespread in the world. This is the socalled professional-didactic translation, which leads to acquiring the translation skill and obtaining the title of professional translator.

In conclusion, as opposed to glottodidactic translation, which functions as a means of attaining language competence as the principal aim of the teaching process, in professional-didactic translation language competence is a sine qua non, functioning in a way as a means of attaining professional translation as the aim.

Translation didactics or translator training is a constituent part of the applied translation study and it includes teaching methods, testing methods, and curriculum design.

\subsection{Translation Teaching at Foreign Language University Studies}

In addition to being applied in foreign language teaching at different levels, and in education and teaching of professional translators, translation is also on the curriculum of language departments at a great number of world universities. In this context, translation is a means in teaching and testing the acquired knowledge of a foreign language, but also an aim, since it attracts huge attention as a separate, autonomous skill meant to approach students in a practical way. Translation included in this kind of teaching activity is somewhere in between the two previously mentioned kinds of translation - glottodidactic and professional-didactic, but it can be closer to one or the other depending on the prioritised aims, which again depend on a number of different factors.

In reference books, authors frequently fail to differentiate between translation in foreign language teaching in general (the grammar-translation method and its variants) and translation at foreign language university studies. On the other hand, most authors who deal with applied translation studies never miss an opportunity to emphasise that language teaching translation (also including translation at philology studies) should in no way be connected to translation in the teaching and education of professional translators. While in the first case we think that it is exactly this difference that should necessarily be stressed, in the second case we agree with those who question the need for insisting on the differences, whose existence we in no way wish to deny ${ }^{18}$. To be more specific, by

${ }^{18}$ Here we agree with Carreres when she says: "While it is important to recognise the distinction between the teaching of translation as an end in itself (professional translator training) and its role as a means of learning a 
introducing the translation of authentic texts of different kinds into foreign language teaching at the university level and using it in this environment, together with improving language knowledge and skills, students are at the same time naturally guided into a translation process and the main principles of translation competence, thus becoming aware of its complexity. In our opinion, this should by all means be regarded as an additional benefit, especially in situations when there is a lack of nation-wide professional schools and university courses specialized in translator training. In these situations, translation included in a foreign language university course can serve and has to serve as a means of allowing students to master the basics of translation process, to have an insight into a complex act of translation, and to form a base for further professional development in this field ${ }^{19}$.

Positive aspects and multiple benefits of pedagogical translation, especially at the university level, are dealt with by many contemporary authors (e.g. Peverati 2014, Cook 2010, House 2009, Machida 2008, Carreres 2006, Liao 2006, Preložníková and Toft 2004, Sewell 2004, Gomes Ferreira 1999, Kasmer 1999, Faber 1998, Pym 1992)

\section{Critical literature overview}

The question of the place and role of translation in foreign language teaching is popular nowadays almost to the same extent as when, at the turn of the twentieth century, the Reform Movement was formed, soon followed by the direct and audio-lingual approaches based on the very criticism of the grammar-translation method, which had already been dominant for two centuries. Translation used in foreign language teaching and learning has gone through different phases and reached two extremes. As the initially main method, even in its explicative role, during a period it was completely rejected, not

language, in my view this distinction has often been overemphasized to the point of impairing a productive exchange between the two areas. In this regard, I believe it can be helpful to view the translator as a life-long learner and the language learner as a natural translator". (Carreres, 18)

${ }^{19}$ In this regard, Preložníková and Toft (95) notice the following: „For some regions, there are periods when language graduates are likely to encounter translation during their careers. It is therefore necessary to have some form of translation training within language degrees. It has to be recognized that this will not produce professional translators, but can produce competent translators who will be able to play an active role in the wider market until the market no longer requires the services of less-qualified ones". 
only as useless, but also as harmful and counterproductive (the direct and audio-lingual methods ${ }^{20}$ ). At the root of the opposite views on the pedagogical use of translation lay primarily a contradictory view on the use of the mother tongue in teaching a foreign language.

Meanwhile, the development of new linguistic theories and the theories of language learning and acquisition was also reflected in the formation of new methods, approaches, and techniques in foreign language learning. In the second half of the twentieth century, applied linguistics, translation studies, and contrastive linguistics were developed. New knowledge shed new light on the translation process and the importance of the mother tongue in learning a foreign language. Naturally, there has been a change in the views on pedagogical translation, and there is an increasing number of authors ${ }^{21}$ who stress the need for re-assessment of its role and who try to prove that it completely fits in with contemporary tendencies in glottodidactics. Therefore, they claim that, if used and combined with other language exercises in a right way and to a right extent, it can significantly contribute to teaching and learning a foreign language.

Although the Common European Framework for Languages, defined by The European Council in 2001 excludes the translation skill from the list of the basic skills which are the final aim of foreign language teaching at $A, B$, and $C$ levels, there are more and more experts who think that this kind of rejection is unacceptable, because, as Calvi (8-9) explains, from both the communicative and pragmatic aspects, the skill in using a language in a real situation by no means excludes the translation skill.

\subsection{Translation and Language Teaching - Negative Views}

The first "more organised" opponents of translation usage in foreign language teaching appeared in the second half of the nineteenth century and formed the so-called Reform Movement, a

20 The direct and audio-lingual methods, as well as the communicative approach, which will replace them later on, shift their focus from the reading and writing skills to the speaking and listening skills. The main aim of foreign language teaching becomes the attainment of "communicative competence", acquisition of a language pragmatics, while the grammatical rules are left to be learned deductively through the use of and contact with a living language.

${ }^{21}$ Keith and Mason 1987, Duff 1989, Sewell and Higgins 1996, Malmkjær 1998, Schaffner 1998, Cook 2001, 2010, Carreres 2006, Di Sabato 2007, Landone 2008, Witte et al. 2009, House 2009, Leonardi 2010, Pym, Malmkjær, Plana 2013, Peverati 2014, Druce 2012, 2015 and others. 
group of European language teaching theoreticians who advocated an approach to language learning "more natural" than the grammartranslation method, dominant at the time. These reformers, although somewhat different, shared the beliefs about the main principles on which a new approach to language learning should be based on. One of these principles, which is here of particular interest to us, reads as follows: translation should be avoided, even though the mother tongue could serve as useful when explaining new words or checking comprehension.

The most heard and, we could easily say, the most extreme critics of pedagogical translation were the proponents of the direct and audio-lingual methods, formed at the end of the nineteenth century. These critics became enormously popular by advocating a belief that a foreign language could and should be acquired following the principle of acquiring the mother tongue. These methods focus on speaking, while in extreme cases they completely reject the use of the mother tongue and translation in teaching, defending their views by claiming that the mother tongue can only disturb the natural acquisition of a foreign language and provoke negative transfer from one language into the other, thus causing only confusion in the learners and leading them to make mistakes they would not otherwise make. One of the main principles of the direct method is: Never translate: demonstrate. However, as early as at the time of its greatest "expansion", this method was criticised even by the proponents of the Reform Movement, among other things due to such a radical rejection of the classroom use of the mother tongue, which could be counterproductive, extremely impractical and uneconomical. ${ }^{22}$

Not even within the communicative approach, whose popularity replaced the audio-lingual and similar methods, and which is still dominant today, both in the classroom and in textbooks used in foreign language teaching, there is no room for translation exercises. The main goal of the communicative foreign language teaching is to reach communicative competence. Learners should be enabled to naturally use a language in various, real situations, while translation is not felt as a natural communicative activity. Although not even in the communicative approach does translation play a role, it is not entirely

\footnotetext{
22 "Critics pointed out that strict adherence to Direct method principles was often counterproductive, since teachers were required to go to great lengths to avoid using the native language, when sometimes a simple, brief explanation in the students native language would have been more efficient route to comprehension" (Richards and Rodgers, 13).
} 
rejected, at least when its explicative function and the function of text comprehension check are concerned. In the interpretation of the differences between the audio-lingual method and the communicative approach, Finocchiaro and Brumfit (91-93), among other things, talk about the differences based on the place of the mother tongue and translation in foreign language teaching, where, contrary to the principles of the audio-lingual method, the communicative approach allows a sensible use of the mother tongue when possible, and resorting to translation when the learners feel the need for it, or when they find it useful.

The most frequent arguments against the application of translation in foreign language teaching which appear in theory ${ }^{23}$ can, therefore, be defined in several general views:

1. The use of the mother tongue, included in translation exercises, leads to negative interference between two languages. More specifically, translation makes learners always see one language from the point of view of the other language, which disturbs the natural learning of the foreign language and makes it impossible for the learners to "think in the foreign language", and is therefore harmful and counterproductive.

2. Translation is in itself an unnatural activity, highly specialised even, which in no way helps acquiring the four basic language skills: comprehension, speaking, reading, writing. Translation is most often seen as a specific skill, the fifth one, which refers to perfect knowledge of the mentioned skills. Freddi (239) says that a translated text can only serve as recognition of a good translation ability.

3. Translation limits the use of a language to only two skills (reading and writing) and by doing it a person acquires passive knowledge of the language.

4. Translation is a method which can lead to good results in working with learners who have a talent for literature and who enjoy grammatical and lexical specificities of a language, but not in working with average learners. In addition, translation should be used only for teaching professional translators.

5. Translation creates a wrong picture of each individual word having an equivalent in another language. The practice of translation in foreign language learning leads to obsession with individual words.

6. Translation is an exercise which demotivates learners (especially the translation in the L1-L2 direction), as they can never

${ }^{23}$ Gatenby 1948/1967, Lado 1964, Krashen 1987, Marsh 1987, Coleman 1986. 
reach the level of precision and stylistic perfection which characterises the professor's translation.

7. Translation into $L 2$ clashes with the professional ethics claiming that translation should exclusively take the L2-L1 direction. At the root of this rule lies a belief that only by translating into the mother tongue can a person attain professional standards. Therefore, translation into $L 2$ is not only useless and counterproductive, but it can also lead students to believe that they are qualified for professional translation in this direction.

\subsection{Translation and Language Teaching - positive views}

In relation to the above-mentioned negative views on pedagogical translation, we will list the following remarks and counterarguments under the following points $(\mathrm{a}-\mathrm{e})$ :

a) The listed negative views mainly refer to the translation understood in the manner of the grammar-translation method ${ }^{24}$, most often in the mother tongue $\rightarrow$ foreign language direction.

In the context of foreign language teaching, translation has usually been connected to this, largely outdated foreign language teaching method. The truth is that, even at the time when it was most criticised, this method survived and, for different reasons, in its more or less changed, "modernised" forms, it still survives in foreign language teaching, regardless of the teaching level ${ }^{25}$. Still, today there is an increasing number of authors who tend to root out the disbelief and distrust gathered around the notion of translation in foreign language didactics. What has caused the appearance of these feelings is exactly its immoderate, inadequate, and in a way exclusive use within the framework of the mentioned traditional grammartranslation method. Basing their views and arguments on the results of modern research in the field of the translation study, cognitive linguistics, and the methodology of teaching, these authors argue for the revaluation and reassessment of the importance, role, and place of translation in contemporary glottodidactics. In various ways, they tend to prove that, if applied in a right way, with a right aim, to a sensible

\footnotetext{
24 "Most criticisms of translation apply only to the limited and idiosyncratic uses of translation in the grammar-translation method and overlook the fact that translation can be used in many other ways". (Duff, 5-18)

${ }^{25}$ See: Carreres, 2, Di Sabato 2007, 48, Balboni, 233-234.
} 
degree $^{26}$, and, most of all, in combination with other language exercises, translation can be very useful and it can lead to excellent results in foreign language teaching. Also, it is important to stress that from this, we can say positive perspective, translation is no longer regarded as a grammatical exercise (which is typical of the grammartranslation method), but as production of text, that is as a specific form of communication.

Besides the fact that there is little empirical evidence that is conclusive either for or against the use of translation activities in the foreign language classroom (Pym et al. 2013, Källkvist 2004; 2008), the main argument in favour of pedagogical translation Schjoldager 2004, 135) limits to the following standpoints, which she quotes from reference books:

- Translation improves language knowledge, verbal agility (Sewell, 142), linguistic accuracy (Duff, 7), and promotes critical reading (Stibbard, 15).

- Translation into the mother tongue saves time needed to check the text comprehension (Stibbard, 15), and helps to advance the passive knowledge of the foreign language which is being learned (Fraser, 112).

- Translation into a foreign language improves the knowledge and the active mastering of a foreign language (Snell-Hornby, 21).

- Translation into a foreign language has another good side, which is reflected in benevolently "forcing" learners to express a certain imposed idea/content in that language. This makes them step into its unknown spheres, otherwise avoided due to a fear of making writing mistakes (Duff, 7, Cook, 119, Campbell, 58).

To these views, we would like to add a fact that translation into the mother tongue serves as one of very efficient ways of evaluating possible flaws in language knowledge and language competence, in both a foreign language and the mother tongue, and also in the familiarity with extralinguistic reality, especially the one referring to the culture which uses the language in question. In the same way, the exercises in translation into the mother tongue based on the principle of learning through mistakes can help to fight the mentioned flaws.

b) The image of the role of the mother tongue in foreign language learning, which forms the base for the majority of the listed

26 "Translation is like a medicine in that if you get the right dose properly administrated it will have a curative effect; to the contrary, when used injudiciously it can prove harmful." (Danchev, 40). 
negative standpoints, does not agree with the stance coming from contemporary cognitive theory of learning.

As House (59) says, the hypothesis that there is a negative influence of the mother tongue on foreign language learning has never been experimentally proven. Furthermore, contemporary theories on the way in which a foreign language is learned claim that, in learners' brain, it is natural and normal to have two simultaneous activities of the two languages and a shift from one code into the other one. Continuing the research showing that, although the lecturer in the classroom does not use the mother tongue, the learners make a comparison with it in their minds, feeling the mother tongue as a framework of reference, and "translate silently", Carreres (6) claims that translation can help the learner exactly to systematise and rationalise the learning mechanism, which is already taking place in the subconscious of his/her mind.

Translation as a language exercise, therefore, helps to develop the awareness of formal and functional differences and similarities between the mother tongue and a foreign language, which is exactly what prevents the negative interference from one language into the other $^{27}$, and especially, as House (64) notices, translation suits a certain type of learners, such as mature people, university students, or scientists, who are more in favour of a systematic comparison between the mother tongue and a foreign language at the level of the word, sentence, text, collocation potential, and pragmatic use.

As for the claim that translation creates a wrong picture of each individual word having its equivalent in another language, Snell Hornby (24-25) notes that, if translation is used in the classroom in a right way, it prevents learners from this exact possible and naive belief, which could be a negative consequence of translation using the wordby-word method, typical of the grammar-translation method.

In favour of the positive view on translation in foreign language teaching, many authors emphasise its significance in both acquiring and evaluating the skill at "reading for understanding". In his research on the role of translation as a cognitive strategy in the process of text comprehension written in a foreign language, Kern (442) claims that it

\footnotetext{
27 "Using translation as an aid to communicative competence and as powerful consciousness-raising procedure, [...] paradoxically, counteract interference from the mother tongue - the very reversal of the strongest argument against translation in the past" House (69).
} 
is translation exactly that learners use to a large degree in order to understand the text.

As for the "natural" acquisition of a foreign language, using the principle of the acquisition of the mother tongue, it was already proven in the negative practice of the direct and audio-lingual methods that, for a number of different reasons, it was naive and impossible to expect this in real conditions.

c) The standpoint that translation exercises demotivate the learner must not be generalised in any way, at least when it comes to translation at the university level of foreign language teaching.

It seems that in this respect the main role is played by the way in which translation is used in class and the manner in which tasks are presented to learners/university students. If translation exercises include appropriate texts, chosen on the basis of their suitability for the needs of a certain level of language competence, if the attention (especially at lower levels of language competence) is primarily focused on the process instead of the product of translation, and if a discussion about possible translation versions is involved, there is no room for frustration and a lack of motivation. On the contrary, in reference books we find papers talking about a positive view on translation by foreign language university students, and this kind of view is also supported by our research carried out at the language departments of the Faculty of Philology at University of Montenegro. To this we are going to dedicate one of the following sections.

d) Only in ideal cases and in theory is it possible to image a translator who translates only into his/her mother tongue - practice tells us an entirely different story.

This counterargument refers to the last of the listed negative views, which speaks specifically of translation in the mother tongue foreign language direction. The claim that only in translation into the mother tongue can professional standards be attained has probably survived due to the fact that for a long period of time, the only and the main subject of research in the field of translation used to be literary translation, and in this case, the same claim is most often true. However, today there is a huge demand for narrowly specialised translators in the field of economics, law, business, etc, who possess certain professional knowledge of a certain area of study, thus also being familiar with its specific terminology, even to a larger degree than an average native speaker who is not specialised in the given area of human knowledge. Also, as Schjoldager (136-137) notices, it is unrealistic to expect every language to have a translator-native speaker. In this respect, the authoress stresses the example of the 
English language most of all, noting that there is less interest in learning foreign languages in English-speaking environments than in other speaking environments. As an example, she mentions a lack of the translators who translate from Finnish and Danish into English. A similar principle can also apply to many other languages. With regard to this problem, some authors point out that in language learning at the university level translation into L2 must in no way be neglected as it is a skill which the students will be needing in professional life. ${ }^{28}$

Anyway, when it comes to the direction of translation, we think that translation into a foreign language and translation into the mother tongue should be regarded as two separate processes, and that their own specific characteristics should be taken into consideration, both when introducing translation into foreign language teaching and when discussing its role in this kind of teaching. It is noticeable that reference books most often talk about translation in a generalised way (while this term frequently refers only to translation into a foreign language) thus placing two different processes under the same umbrella. Likewise, the same conclusions and statements cannot apply to written and oral translation equally. With regard to this kind of imprecision, we disagree with both the opponents and adherents of pedagogical translation.

e) The criticism of pedagogical translation is most often generalised and refers to foreign language teaching in general, regardless of the level at which it takes place.

The role of translation in foreign language teaching cannot be the same and equally important at all language learning levels; therefore, it is inappropriate to approach this role always in the same manner. The motive for and aim of studying a language at the university level in no way can or should correspond to the motives for and aims of learning a language at the elementary and secondary education level, or at the level of private schools and foreign language courses, applied or specialist studies. If at other levels of learning the aim is primarily to attain the speaking skill and master competence in a specific segment of language (e.g. technical languages), at the philological university studies, a foreign language is studied in detail at all its levels, whereas its structure is compared to the structure of the mother tongue with the aim of increasing the awareness of the similarities and differences between the two languages, and also between the cultures of the peoples using these languages.

${ }^{28}$ Carreres (6), Larsen (95), Klein-Braley and Franklin (54-55). 


\section{Empirical Research}

In the beginning, the arguments in favour of reintroducing translation in LS classrooms were mostly based on knowledge of the translation study, cognitive linguistics, glottodidactics, etc; personal impressions and individual reflections resulting from the practice of certain authors, and few sporadic empirical pieces of research. Apart from the fact that the majority of these few pieces of research included an analysis of usefulness of the grammar-translation method in foreign language teaching and learning, they mainly concerned translation into a foreign language and usually dealt with an analysis of reasonableness of its role in evaluating the knowledge of learners/students (e.g. KleinBraley 1996, Buck 1992, Larsen 1990).

After years of predominantly theoretical work, the $21^{\text {st }}$ century literature on the subject shows us "the higher incidence of empirical contributions that contrast and measure the impact of translation-based and non-translation-based activities on students' performance in different areas of language competence (e.g. writing, vocabulary, grammar)". (Peverati, 15)

Nevertheless, the question about whether translation as a teaching activity leads to better results in foreign language learning still does not have a unique, generally acceptable and generally accepted answer. The research findings vary, depending on the type of translation involved and student levels. As Peverati (15) summarizes it, some of these studies do not show "significant enhancement deriving from the use of translation over other monolingual activities, or even negative effects (e.g. Schjoldager 2003, 2004, Källkvist 2004, 2008)", while some of them show that, "compared to non-contrastive tasks, translation task generate higher levels of student-initiated vocabularyrelated reflection and classroom interaction (e.g. Källkvist 2013), more syntactic accuracy (e.g. Ghia 2011, 2012), as well as more vocabulary retention (e.g. Lertola 2012)." (Peverati, 15).

\subsection{Aim, Role, and Importance of Translation in Language Teaching at the University Level from the Perspective of Students \\ When it comes to empirical research, in addition to the revision of the purposefulness of translation use in foreign language teaching, which we have previously briefly mentioned, in reference books we can also find research dealing with the relation between university teachers or university students of foreign languages and translation as teaching activity, and with the students' expectations in terms of its application in the teaching process (e.g. Pym et al. 2013,}


Peverati 2014, Machida 2008, Liao 2006, Horwitz 1988, Hsieh 2000, Prince 1996).

The results of such research were also presented by Carreres (2006). With the aim of proving the claim that translation should be a constituent part of teaching activities at the university level language studies, she conducted research taking a sample of students of the Spanish language at the University of Cambridge. The research took the form of a questionnaire and was supposed to provide data on how students see the importance and purpose of translation exercises at the university level undergraduate studies. The results showed that all of the participants (31 in total) thought that translation should be a constituent part of the teaching programme. In addition, they regarded this teaching activity as useful, while more than a half of them stated that translation exercises were more useful than all the other language exercises. Also, in favour of her hypothesis that insisting on a strict division between glottodidactic and professional-didactic translation does more damage than good, and that in practice it is difficult to draw this dividing line, is also the fact that the students thought that, to a certain extent, translation exercises also prepared them for professional translation practice, although this was not included in the main aim of translation teaching within the undergraduate foreign language programmes at the mentioned University.

Similar results came from the research we conducted with two generations of foreign language students. ${ }^{29}$ Within this research students from five language departments at the Faculty of Philology of the University of Montenegro (Department of English, French, German, Russian, and Italian languages and literature), were questioned about the place and purposefulness of translation teaching. It is necessary to emphasize that at each of the five listed language departments, translation is primarily used as a language exercise, that the aim of the teaching is not training professional translators (but language teachers), and that the theoretical bases of translation are not included in the teaching plan and programme at this level of the studies.

The questionnaire was anonymous, it contained eight closed questions, and was answered by 127 undergraduate students of the second and third years at the five listed departments, regardless of their sex, success, and maturity, or of whether they had gained any knowledge of the given foreign language during their previous

\footnotetext{
${ }^{29}$ One part of the research results was presented in the proceedings of the international scientific conference: Piletić, D. (2011).
} 
education. The students were allowed to circle one of the three answers offered to every question, and also to comment on each of the chosen answers. The fact that only a few questions, and the very small percentage of them ( $2 \%$ at the most), remained unanswered, that the great majority of the questioned students chose to comment on their answers, as well as the very content of the comment, lead us to conclude that the students were interested in this type of cooperation, that their answers were sincere, therefore that the survey was a success. The table with the detailed results regarding individual questions and the students' comments on individual questions are to be found in the Appendix $(a, b)$ to this paper.

In addition to the fact that students of different foreign languages studied at various departments were the ones who filled in the questionnaire, that the way in which the exercises themselves were conceptualised differs depending on the very department, and that, naturally, there are individual differences among professors who coordinate the exercises, by analysing the results, we have also derived a general conclusion, which says that:

- $\quad 97 \%$ of students think that translation exercises should exist at the foreign language undergraduate studies;

- $\quad 97 \%$ of students reckon that translation studies are important in both language learning and gaining the translation skill;

- $\quad 98 \%$ of students think that exercises in translation from the mother tongue into a foreign language are useful in foreign language learning;

- $\quad 97 \%$ of students hold that exercises in translation from a foreign language are useful in advancing the knowledge of a foreign language and the mother tongue;

- $\quad 97 \%$ of students think that exercises in translation from a foreign language are useful in gaining translation competence;

- $\quad 96 \%$ of students like attending translation exercises.

Therefore, in a similar way as the results of the research conducted by Carreres (2006), our results show that the students eagerly attend translation exercises and think that with their help they can advance in foreign language learning and gaining the translation skill. However, there arises a question whether their opinion can be rationalised and to what extent it depends on their presumption concerning translation itself. This makes us go back to a previously mentioned statement that we still do not have empirically gained results which could give us concrete answers. Still, we have to agree that, if the students see translation as useful and if they eagerly follow 
translation teaching, the main, although not the only one, precondition for deriving a benefit from translation has been fulfilled.

Penelope Sewell (2004) tried to offer possible answers to the question why students love translation classes so much. In a picturesque title of her work: "Students buzz round the translation class like bees round the honey pot-why?", she makes a statement at the same time posing a question, to which, as she says, she tends to find an answer in an individual impression based on her teaching practice but also on scientifically rooted facts.

Sewell, more precisely, notices that her students at the Department of French at the Birkbeck University of London, in addition to having language classes conceptualised very well according to the principles of the communicative approach, constantly ask for written translation exercises. This fact inspired the authoress to try to understand what it is that translation has to offer, being at the same time an element a communicative class is lacking in. In this respect, she offers five possible explanations supporting them by scientific data on foreign language learning, found in psychology and psycholinguistics. More precisely, the authoress supposes that the students like translation because it has a positive influence on strengthening their self-confidence, makes it possible for them to present themselves in front of the colleagues and the professor in an as positive light as possible, to get satisfaction from the effort they have made in the form of translation as a product of their individual work, to feel autonomous. In her last argument, Sewell relies on the theory of cognitive styles and says that translation definitely suits introverts. As for the cognitive styles, House (64) also notes that translation suits students as they belong to the group of learners who, during the learning process, eagerly rely on a systematic comparison between the mother tongue and a foreign language.

\section{Conclusion remarks}

The notion of translation is inextricably linked to the notion of foreign language didactics. Whether this connection has positive or negative connotations, the fact is that translation has been used as the method or one of the methods or techniques in foreign language learning and teaching. Although in its long history of existence and application, this method has undergone changeable destiny, it is, in a more or less modified version, still present today at different language learning levels, but with an important difference: translation is no longer the only language exercise, whereas the acquisition of grammar is not the sole aim of language learning. In addition to being applied in 
foreign language teaching at different levels, and in education and teaching of professional translators, translation is also on the curriculum of language departments at a great number of world universities.

As opposed to the standpoint of a certain number of experts in applied translation studies, who define a clear boundary between glottodidactic and professional-didactic translation, the results of the listed pieces of research indicate that students expect the pedagogical translation, included in the programme of the foreign language university studies, to provide them with specific training that will prepare them for work on the translation market, which is especially reasonable in those situations when social circumstances impose this as a need.

\section{Works Cited:}

Balboni, P. Le sfide di Babele, Torino: UTET Università, 2006.

Calvi, M. V.. La traduzione nell'insegnamento delle lingue e nello studio dei linguaggi specialistici, 2003

http://www.ledonline.it/ledonline/tradurrespagnolo_02_calvi.pdf. 23.04.2019

Campbell, S. Translation into the Second Language. London and New York: Longman, 1998

Carreres, A.. Strange bedfellows: Translation and Language teaching. The teaching of translation into $L 2$ in modern languages degrees; uses and limitations, 2006

http://www.cttic.org/ACTI/ papers/Carreres.pdf. 22.04.2019

Coleman, J. A. "Requiem for the Prose? The disappointing reality behind the cherished ideals". In Modern Languages in Scotland, 29. (1986): 98-105.

Cook, G.. "Use of translation in language teaching". In M. Baker (Ed.), RoutledgeEncyclopedia of Translation Studies, New York and London: Routledge, (2001): 117-120

Cook, G.. Translation in Language Teaching, Oxford University Press, 2010

Danchev, A. "The Controversy over Translation in Foreign Language Teaching". Translation in Foreign Language Teaching. Paris. Round Table FIT-UNESCO. (1983): 40-45.

Druce, P.M. "Attitudes to the Use of L1 and Translation in Second Language Teaching and Learning. In Journal of Second Language Teaching and Research. Vol 2, No 1, 2012 
http://pops.uclan.ac.uk/index.php/jsltr/issue/view/11. 23.04.2019

Druce, P.M. "Attitudes to the Use of L1 and Translation in Second Language Teaching and Learning. In Journal of Second Language Teaching and Research (Part 2), Vol 4, No 2, 2015. http://pops.uclan.ac.uk/index.php/jsltr/issue/archive.23.04.20 19.

Duff, A. Translation, Oxford, OUP, 1989/1992

Di Sabato, B. "La traduzione e l'apprendimento/insegnamento delle lingue." In Studi di Glottodidattica (2007): 47-57

http://www.glottodidattica.net/Articoli/articolo1_04.pdf. 15.10.2010

Di Sabato, B. "Apprendere a mediare. Per un nuovo ruolo della traduzione nella classedi lingue". In Traduttori e traduzioni, C. Vallini, V. Caruso, and A. De Meo (Eds). Naples: Liguori, (2011): 227-243.

Faber, P. "Translation Competence and Language Awerness". In Language Awerness 7, 1. (1998): 9-21

Finocchiaro M, Christopher B. The functional-notional approach. Oxford: Oxford University Press, 1983

Fraser, J. "'I Understand the French, But I Don't Know How to Put It Into English'. Developing Undergraduates' Awareness of and Confidence in the Translation Process". In P. Sewell and I. Higgins (Eds), Teaching Translation in Universities: Present and FuturePerspectives, London: CILT. (1996): 121-134.

Freddi, G. (1999). Psicolinguistica, sociolinguistica, glottodidattica, Torino, UTET.

Gatenby, E. V. "Translation in the Classroom". W. R. Lee (ed.), E.L.T.Selections 2. Articles from the journal English Language Teaching, London: Oxford University Press. (1948/1967): 6570.

Ghia, E. "The acquisition of L2 syntax through audiovisual translation". InA.Serban, A. Matamala, and J.-M. Lavaur (Eds) Audiovisual Translation in Close-Up. Practical and Theoretical Approaches, Bern: Peter Lang. (2011): 95-112.

Ghia, E. Subtitling Matters. New Perspectives on Subtitling and Foreign Language

Learning. Bern: Peter Lang, 2012.

Gomes Ferreira, S. M. Following the Paths of Translation in Language Teaching: From Disregard in the Past Towards the $21^{\text {st }}$ Century, 1999.

https://dialnet.unirioja.es/descarga/articulo/4925307.pdf. 15.10. 2010. 
González Davies, M. Multiple Voices in the Translation Classroom, Amsterdam and Philadelphia, John Benjamins, 2004.

González Davies, M "Translation: Why the Bad Press? A Natural Activity in an Increasingly Bilingual World". Humanising Language $\begin{array}{llll}\text { Teaching } & 9 & \text { (2), }\end{array}$ http://www.hltmag.co.uk/mar07/mart02.htm. 05.02.2014.

House, J. Translation, Oxford University Press, 2009.

Källkvist, M. "The effect of translation exercises versus gap-exercises on thelearning of difficult L2 structures: Preliminary results of an empirical study". In K. Malmkjær (Ed) Translation in Undergraduate Degree Programmes.Amsterdam and Philadelphia: John Benjamins, (2004): 163-184.

Källkvist, M. "L1-L2 translation versus no translation: A longitudinal study of focus-on-form within a meaning-focused curriculum". In L. Ortega and H. Byrnes (Eds). The Longitudinal Study ofAdvanced L2 Capacities. London and New York: Routledge, (2008): 82-2002.

Källkvist, M. "Languaging in translation tasks used in a university setting: Particular potential for student agency?". In The Modern Language Journal 97 (1), (2013): 217-238.

Kasmer, W. "The role of translation in the EFL/ESL classroom", 1999. www.birmingham.ac.uk/Documents/collegeartslaw/cels/.../ka smer2.pdf. 5.12.2013

Keith $\mathrm{H}$, Mason I. (Eds). Translation in the modern languages degree, London, Centre for Information on Language Teaching and Research, 1987.

Klein-Braley, C. and Franklin, P. "The foreigner in the refrigerator, remarks about teaching translation to university students of foreign languages". In K. Malmkjaer (Ed.), Translation and Language Teaching. Manchester, UK: St. Jerome. (1998): 5361.

Klein-Braley, C. "Teaching Translation, a Brief for the Future". In P. Sewell, I. Higgins (Eds), Teaching Translation in Universities. Present and Future Perspectives, London: Association for French Language Studies \& Centre for Information on Language Teaching and Research. (1996): 15-30.

Krashen, S. D. Principles and Practice in Second Language Acquisition. New York: Prentice-Hall International, 1987.

Lado, R. Language Teaching. A Scientific Approach. New York, San Francisco, Toronto and London:McGraw-Hill Inc, 1964.

Landone, E. Consciousness-raising e la traduzione per unità lessicali, 2008. 
https://cvc.cervantes.es/literatura/aispi/pdf/14/14_145.pdf.5. 12.2013.

Lavault, E. Les fonctions de la traduction dans l'enseignement des langues, Paris,Didier Erudition, 1985.

Leonardi, V. The Role of Pedagogical Translation in Second Language Acquisition. From Theory to Practice. Bern: Peter Lang, 2010.

Lertola, J. "The effect of the subtitling task on vocabulary learning". In A. Pym and D. Orrego-Carmona (Eds)Translation Research Projects 4..Tarragona: Intercultural Studies Group, (2012): 6170.

Liao, P. "EFL learners' beliefs about and strategy use of translation in English learning" RELC Journal 37:2. (2006): 191-215.

Machida, S. A Step Forward to Using Translation to Teach a Foreign/Second Language, 2008. https://pdfs.semanticscholar.org/ee42/18ea86469b116d5c3e5 b938aa86cdb94aead.pdf 5.10.2010.

Malmkjær K. (Ed.). Translation and language teaching. Languageteaching and translation. Manchester, St Jerome, 1998.

Malmkjær K. (Ed.) Translation in Undergraduate Degree Programmes, Amsterdam/Philadelphia, John Benjamins Publishing Company, 2004.

Marsh, M. "The value of $\mathrm{L} 1>\mathrm{L} 2$ translation on undergraduate courses in modern languages". In H. Keith \& I. Mason (Eds), Translation in the Modern Languages Degree:Proceedings of a conference held at Heriot-Watt University, Edinburgh, 5-7 Jan. 1986. Edinburgh: CILT, (1987): 22-30

Peverati, C. Translation in University Foreign-Language Curricula: An Analysis of Teachers' Attitudes, with Reference to Vocational and Transferability Criteria - Doctoral thesis, Universitat Rovira I Virgili. Tarragona. Intercultural Studies Group, Researchin mediation between cultures, 2014.

https://www.tesisenred.net/bitstream/handle/10803/292368/TESI.pdf ?sequence=1\&isAllowed=y. 10. 06. 2019.

Piletic, D. "Prevođenje i nastava stranih jezika: neki pozitivni stavovi". In Julijana Vučo and Biljana Milatović (Eds) Stavovi promjena promjene stavova. Međunarodni tematski zbornik radova. Nikšić: Filozofski fakultet, (2011): 525-533

Preložníková, S, Toft, C. "The role of translation studies within the framework of linguistic and literary studies". In: Malmkjaer K. (Ed.), Translation in Undergraduate Degree Programmes, 
Amsterdam/Philadelphia, John Benjamins Publishing Company, (2004); 83-97.

Pym, A. "Translation error analysis and the interface with language teaching," in C. Dollerup and A. Loddegaard (Eds) Teaching Translation and Interpreting, Amsterdam/Philadelphia. (1992): 279-288.

Pym, A., Malmkjær, K., Plana, M. Translation and language learning: The role of translation in the teaching of languages in the European Union. A Study. Directorate-General for Translation, European Commission. European Union 2013.

Richards J, Rodgers T. (Eds). Approaches and Methods in Language Teaching. Cambridge, Cambridge University Press, 2001.

Schjoldager, A. "Translation for language purposes: Preliminary results of an experimental study of translation and picture verbalization". In Hermes Journal of Linguistics 30, (2003): 199213.

Schjoldager, A. "Are L2 learners more prone to err when they translate?" In K. Malmkjær (Ed) Translation in Undergraduate Degree Programmes, Amsterdam and

Philadelphia: John Benjamins, (2004): 127-149.

Sewell P, Higgins I. (Eds) Teaching Translation in Universities, London, AFLS-CILT, 1996.

Sewel, P. "Students buzz round the translation class like bees roundthe honey pot - why?". In Malmkjær K. (Ed) Translation in Undergraduate Degree Programmes, Amsterdam/Philadelphia, John Benjamins Publishing Company, (2004): 151-163.

Stibbard, R. "The use of translation in foreign language teaching". In Perspectives: Studies in Translatology, 2 (1), (1994): 9-18.

Snell-Hornby, M. "Translation as a means of integrating language teaching andLinguistics". In C. Titford \& A. E. Hieke (Eds), Translation in Foreign Language Teaching and Testing. Tübingen: Narr.,(1985): 21-28.

Witte, A. "From translating to translation in foreign language learning". In A. Witte, T. Harden, and A. Ramos de Oliveira Harden (Eds) Translation in Second Language Learning and Teaching,. Bern: Peter Lang, (2009). P: 79-97. 


\section{PREVOĐENJE U NASTAVI STRANIH JEZIKA NA UNIVERZITETSKOM NIVOU}

Različita mišljenja o upotrebi prevođenja u nastavi stranih jezika veoma često dotiču dvije suprotne krajnosti. Ovaj rad će nastojati da predstavi pozitivne stavove u vezi sa ulogom prevođenja u nastavi stranih jezika na univerzitetskom nivou, posebno u situacijama kada u određenoj sredini, za određene jezike, ne postoje univerzitetski kursevi ili škole za profesionalne prevodioce. Kao doprinos pozitivnom odnosu prema upotrebi prevođenja u nastavi stranih jezika na pomenutom nivou, u radu će biti predstavljeni rezultati upitnika koji je obuhvatio studente osnovnih studija stranih jezika na Filološkom fakultetu Univerziteta Crne Gore. Cilj upitnika bio je da se utvrde stavovi i očekivanja studenata u pogledu uloge vježbi prevođenja u usvajanju kako jezičke, tako i osnova prevodilačke kompetencije.

Ključne riječi: školsko prevođenje, prevodilačka kompetencija, prevodilačka didaktika, nastava stranih jezika, jezička kompetencija, univerzitetski nivo.

\section{APPENDIX}

a) A table with the results from the survey of the importance of translation exercises from the point of view of foreign language students

\begin{tabular}{|c|c|c|c|c|c|}
\hline No. & Question & & swer & & \\
\hline \multirow[t]{2}{*}{1.} & \multirow{2}{*}{$\begin{array}{l}\text { Should there be } \\
\text { translation } \\
\text { exercises at the } \\
\text { undergraduate } \\
\text { language } \\
\text { university } \\
\text { studies? }\end{array}$} & $\begin{array}{l}\text { I do not } \\
\text { know }\end{array}$ & No & Yes & $\begin{array}{l}\text { Without } \\
\text { answer }\end{array}$ \\
\hline & & 2 & 1 & $7 \%$ & $\%$ \\
\hline 2. & $\begin{array}{l}\text { Should } \\
\text { translation } \\
\text { exercises enable } \\
\text { the student to } \\
\text { translate or } \\
\text { contribute to }\end{array}$ & $\begin{array}{l}\text { To } \\
\text { enable } \\
\text { the } \\
\text { student } \\
\text { to } \\
\text { translate }\end{array}$ & $\begin{array}{l}\text { To } \\
\text { contribute } \\
\text { to foreign } \\
\text { language } \\
\text { learning }\end{array}$ & Both & $\begin{array}{l}\text { Without } \\
\text { answer }\end{array}$ \\
\hline
\end{tabular}




\begin{tabular}{|c|c|c|c|c|c|}
\hline & $\begin{array}{l}\text { foreign language } \\
\text { learning? }\end{array}$ & $\%$ & $\%$ & $4 \%$ & $\%$ \\
\hline \multirow[t]{2}{*}{3.} & \multirow{2}{*}{$\begin{array}{lr}\text { According } & \text { to } \\
\text { you, to what } \\
\text { extent are } \\
\text { exercises in } \\
\text { translation from } \\
\text { a foreign } \\
\text { language into the } \\
\text { mother tongue } \\
\text { useful for foreign } \\
\text { language } \\
\text { learning? }\end{array}$} & $\begin{array}{l}\text { Not at } \\
\text { all } \\
\text { useful }\end{array}$ & $\begin{array}{l}\text { Fairly } \\
\text { useful }\end{array}$ & $\begin{array}{l}\text { Very } \\
\text { useful }\end{array}$ & $\begin{array}{l}\text { Without } \\
\text { answer }\end{array}$ \\
\hline & & $\%$ & $9 \%$ & $8 \%$ & $\%$ \\
\hline 4. & $\begin{array}{l}\text { According to } \\
\text { you, to what } \\
\text { extent are } \\
\text { exercises in } \\
\text { translation from } \\
\text { the mother } \\
\text { tongue into a } \\
\text { foreign language } \\
\text { useful for foreign } \\
\text { language } \\
\text { learning? }\end{array}$ & $\%$ & $\%$ & $4 \%$ & $\%$ \\
\hline \multirow[t]{2}{*}{5.} & \multirow{2}{*}{$\begin{array}{l}\text { To what extent } \\
\text { are exercises in } \\
\text { translation into } \\
\text { the mother } \\
\text { tongue useful for } \\
\text { mastering the } \\
\text { knowledge of the } \\
\text { mother tongue } \\
\text { itself? }\end{array}$} & $\begin{array}{l}\text { Not at } \\
\text { all } \\
\text { useful }\end{array}$ & $\begin{array}{l}\text { Fairly } \\
\text { useful }\end{array}$ & $\begin{array}{l}\text { Very } \\
\text { useful }\end{array}$ & $\begin{array}{l}\text { Without } \\
\text { answer }\end{array}$ \\
\hline & & $\%$ & $8 \%$ & $0 \%$ & $\%$ \\
\hline 6. & $\begin{array}{l}\text { To what extent } \\
\text { are exercises in } \\
\text { translation into } \\
\text { the mother } \\
\text { tongue useful for } \\
\text { gaining } \\
\text { translation } \\
\text { competence? }\end{array}$ & $\%$ & $8 \%$ & $0 \%$ & $\%$ \\
\hline
\end{tabular}




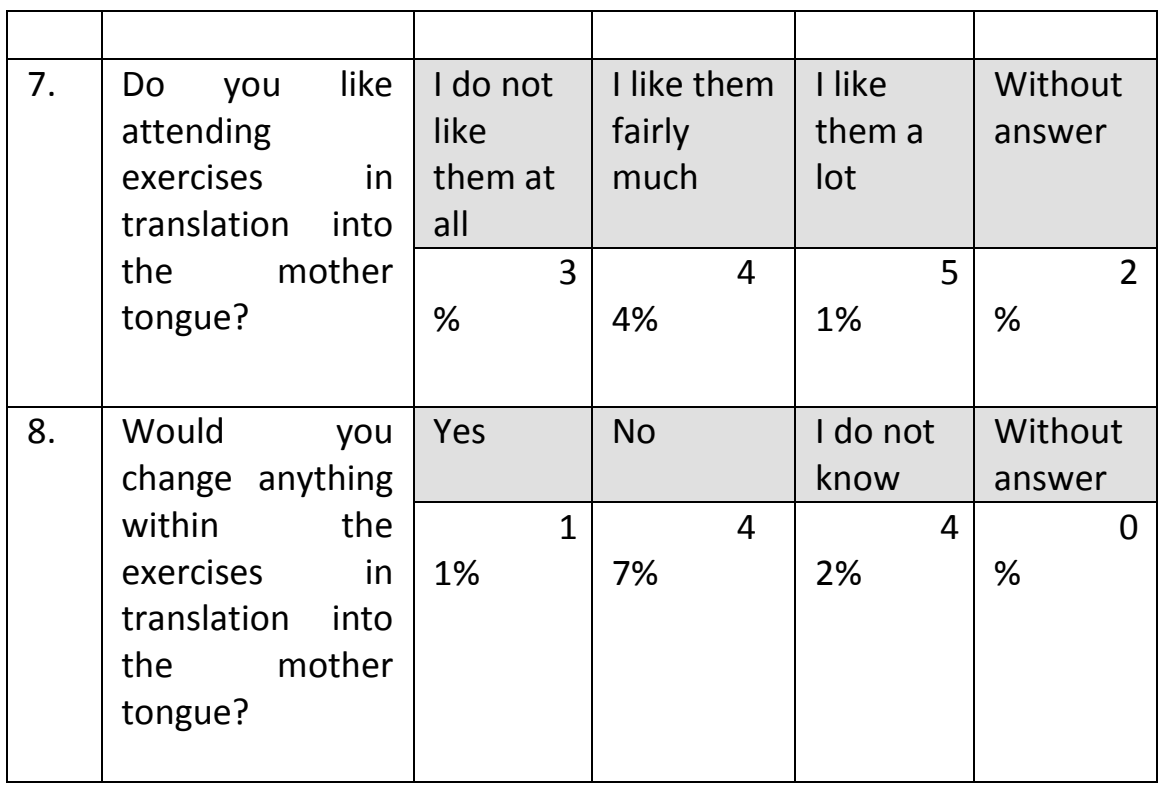

b) Comments on the individual questions from the survey:

Remarking that a fair number of answers are the same, that is that they are repeated several times, we reveal some of them, which refer to each of the eight questions from the survey individually:

(1)

- Not only should translation exercises exist, but they should be started in the very first year.

- The number of translation exercises should be increased.

- By doing translation exercises, we learn the greatest number of words and phrases, we also acquire a certain translation technique, therefore I think that these exercises are more useful than all the other language exercises.

- The studies are serious enough to require this kind of exercises.

- Definitely/ Yes! Yes! Yes! Of course.

(2)

- Both things are important, as we cannot know precisely what we are going to do when we graduate.

- By doing translation exercises, we learn most things.

- Through practising, the student makes a lot of mistakes, and by doing so they also learn a lot, therefore the benefit is a sure outcome.

(3)

- Translation exercises are also important in foreign language learning and assessing the student's language competence.

- They help to form the style and advance the knowledge. 
- New words and constructions are learned.

- They are very useful to me because, with their help, I get familiar with a lot of unknown words, and also because I get the sense of the way in which translation should be done.

- Vocabulary is enriched.

- They are useful for the mother tongue, for a foreign language, and also for developing the feeling for vocabulary.

(4)

- These exercises are more useful than all the others.

- There should be more of these exercise classes.

- Progress in both conversation and written translation.

- This is the more difficult direction of translation.

(5)

- During these exercises, I often come across a word whose meaning in our language I would not be able to tell if I had not found it in an Italian text I was supposed to translate.

-I think that for every type of translation, we should above all possess the core knowledge of our mother tongue.

- While translating, we realise how poor our vocabulary is. We often lack words to express in our own language.

- The student enriches his/her knowledge of both a foreign language and his/her mother tongue.

(6)

- The basic translation technique is acquired.

- The more translation exercises, the more self-confidence while translating.

- With a professor to draw the student's attention to his/her mistakes, the student learns about what is allowed and what is forbidden in translation.

- A feeling for translation is developed.

(7)

- I do not like the texts we translate.

- To be honest, at home I enjoy doing these translations, I do not know if I show it in class, but this is the way it is.

- It is interesting to hear various versions of the translation of one and the same text.

- I do not like all translations we do, but I realise that this is with the aim of improving knowledge.

(8)

- We should use the Internet more during our classwork.

- There should be more exercise classes. 
- The number of students in the classroom should be smaller.

- More technology should be provided.

- There should be one literary work per year for translation.

- Consecutive interpretation should be introduced.

- I would not focus only on the standard, literary and journalistic styles, as is the usual case.

- I find these exercises quite good, but we frequently, for example, do not find the right translation and then, out of a million offered solutions, there is no way I can understand which one is the most correct, so I would like this to change at least a little bit. But the rest is ok. 